DOI: http://dx.doi.org/10.23925/2176-2767.2020v67p447-483

Enviado em: 12/02/2020

Aprovado em: 14/03/2020

\title{
ENTREVISTA COM DURVAL MUNIZ DE ALBUQUERQUE JÚNIOR: AS VEREDAS SUBJETIVAS DE UM HISTORIADOR ${ }^{1}$
}

\author{
VALÉRIA BARBOSA DE MAGALHÃES* \\ DAISY PERELMUTTER**
}

(Com Post Scriptum de Valéria Cazetta)

Paraibano da cidade de Boqueirão e nascido em 1961, Durval Muniz de Albuquerque constituiu-se nos interstícios entre a experiência rural e urbana, entre a origem sulista da mãe e o berço paraibano do pai. A vivência e o trânsito por universos distintos refletiram-se em toda a sua obra e no modo como ele explica e compreende a História.

Durval é um grande narrador, com memória prodigiosa e oratória abrasadora. Suas lembranças ricas em fatos, afetos e significados moldam sua leitura de mundo e a prática como educador. Para nos mantermos fiéis

\footnotetext{
${ }^{1}$ Entrevista realizada em 11 de novembro de 2019, na Escola de Artes, Ciências e Humanidades da USP. Entrevistadoras: Daisy Perelmutter e Valéria Barbosa de Magalhães. Transcrição: Aline Campos dos Reis. Conferência: Valéria Barbosa de Magalhães.

* Docente da EACH/USP. Orientadora no Programa de Pós-Graduação em Movimentos Sociais e Participação Social/USP. Doutora em História Social. Coordenadora do GEPHOM/USP. Orcid: https://orcid.org/0000-0002-6817-4192. gephom@gmail.com.

** Doutora em História pela PUC e pesquisadora do Gephom/USP. https://orcid.org/0000-0001-7877-9956.gephom@gmail.com.
} 
à sua narrativa oral, optamos por não editar as longas frases, quase sem pontuações, e que enfatizam os conteúdos por ele sublinhados, sendo também as marcas distintivas de seu falar paraibano.

Realizada em 11 de novembro de 2019, na Escola de Artes, Ciências e Humanidades da USP (cujo campus está localizado na periferia da cidade de São Paulo, justamente onde se concentra uma das maiores comunidades migrantes do Nordeste), a entrevista sucedeu a palestra que inaugurou o Ciclo de Debates "Nordestes", 2 promovido pelo Grupo de Estudo e Pesquisa em História Oral e Memória da USP. ${ }^{3}$

Nesta entrevista de história oral, buscamos estimulá-lo a retraçar seu percurso pessoal e profissional, destacando experiências formadoras e definidoras de suas escolhas, apostas e valores acadêmicos. Em tom pessoal, ele rememora dimensões da sua vida em família e nos apresenta inspirações teóricas e autores que o influenciaram, a exemplo de Deleuze, Guattari, Rosa Godoy Silveira, Francisco de Oliveira e a escola sociológica paulista, além de Foucault, é claro. Em sua bem urdida narrativa, fica cristalina a forte relação entre a trajetória pessoal e as escolhas acadêmicas praticadas.

${ }^{2}$ O Ciclo de Debates Nordestes está ligado ao projeto "Migrações do Nordeste para o Sudeste: Abordagem Histórico-Crítica, coordenado por Valéria B. Magalhães e financiado pela Fapesp.

${ }^{3}$ Conferência Identidade, Tolerância e Construção da Noção de Nordeste. Durval Muniz de Albuquerque, 11 de novembro de 2019, 14h, EACH/USP. Organização: Valéria B. Magalhães, Valéria Cazetta e Daisy Perelmutter. Grupo de Estudo e Pesquisa em História Oral e Memória/USP e Grupo de Pesquisa Culturas Visuais e Experimentações Geográficas/USP. Apoio e financiamento: Programa de PósGraduação em Estudos Culturais, Programa de Pós-Graduação em Mudança Social e Participação Política/USP. 
Formado em História pela Universidade Estadual da Paraíba, Durval é hoje Professor Titular aposentado da Universidade Federal do Rio Grande do Norte e Professor Visitante da Universidade Estadual da Paraíba, além de bolsista de produtividade do CNPq. Considerado um dos principais historiadores brasileiros da atualidade, seu itinerário acadêmico e solidez teórica têm balançado certezas e desafiado o entendimento da realidade do Nordeste, e, como decorrência, do Brasil. Trata-se de um pensador que também tem desconstruído premissas sobre o próprio fazer do historiógrafo.

Dentre suas inúmeras obras, destacamos: História. A arte de inventar o passado (2007a), na qual o autor discute o conceito de invenção, o fazer do historiador como um produtor de documentos, e os métodos da História, tendo a obra de Foucault como principal referencial teórico. Preconceito contra a origem geográfica e de lugar: as fronteiras da discórdia (2007b), em que ele faz uma densa reflexão sobre as raízes da discriminação contra os nordestinos, abordando a formação do Estado brasileiro e relacionando-o ao preconceito de origem geográfica, à noção de demarcação de fronteiras, e às justificativas formuladas para explicar a discriminação contra essas pessoas. A invenção do Nordeste e outras artes (2009) deriva da tese de doutorado de Muniz, defendida na Unicamp, em 1994. No texto, Durval sistematiza toda a construção que vinha elaborando sobre o Nordeste e que, posteriormente, influenciaria muitos pesquisadores engajados com esta discussão.

Vale destacar seu livro recente, O Tecelão dos Tempos (novos ensaios de teoria da História) (2019), lançado em 2019, no qual Muniz refina suas análises de longa data sobre a profissão do historiador. A publicação uniu 
artigos que evocam asserções como a produção do documento e a construção da História pelo olhar do estudioso, a memória e esquecimento e o ensino da História como proposta de desconstrução de certezas. Trata-se de uma obra desafiadora e que desmantela as mais variadas convicções e dogmas.

Firmando sua centralidade no pensamento historiográfico brasileiro, especialmente voltado ao campo da cultura, Durval vira do avesso certa imagem de Nordeste (seco, atrasado e homogêneo) que se consagrou como a "Verdade", tentando compreender a gênese deste processo histórico, identificando e problematizando quem foram seus atores sociais, quais práticas e discursos foram necessários arregimentar para que esta noção se cristalizasse.

A fim de não retardar a instigante leitura do relato de Durval, encerraremos esta breve apresentação salientando que sua narrativa faz transparecer o nexo atávico que há entre o fazer dos historiadores e as suas próprias trajetórias de vida.

\section{A Entrevista com Durval}

Daisy. Durval, quais são as suas imagens mais primevas do Nordeste? Valéria. Complementando a pergunta da Daisy: tendo isso em vista, você poderia falar um pouco também sobre como essas imagens formaram você como historiador preocupado com o Nordeste?

Durval. Fui uma criança que só nasci na cidade de Campina Grande, mas que cresci no mato, cresci em uma fazenda, na fazenda do meu pai, até os 15 anos de idade. Em uma fazenda localizada justamente em uma área que 
se chama Cariri da Paraíba, mas que faz parte do que normalmente se entende por sertão. É a área mais árida da Paraíba, chove em torno de 200 milímetros por ano.

Valéria. Qual o nome de lá, Durval?

Durval. O município é Boqueirão, fica próximo a Campina Grande, onde está o açude de José Américo de Almeida, que abastece Campina Grande. $\mathrm{Eu}$ cresci nessa fazenda. Inicialmente, meu pai se deslocava periodicamente para uma outra que meu avô deixou, as duas foram deixadas de herança por ele. Essa outra fazenda ficava mais próxima de Campina Grande, em uma região mais úmida, no agreste, e a gente se deslocava de seis em seis meses de uma para outra. Quer dizer, quando você tinha a seca, descia para a área mais úmida, quando começava a chover, aí a gente voltava para essa área mais seca.

Eu cresci conhecendo toda essa realidade, a minha consciência social nasce na realidade de conhecer a miséria de muito perto. Meu pai costumava ter trabalhadores e moradores que chegavam normalmente com meia dúzia de coisas nas costas, que realizavam um contrato meramente verbal, que na maioria do tempo não recebiam salário, não eram remunerados. Recebiam uma casa muito pobre, de taipa e chão batido para morar, o acesso a um pedaço de terra para plantar, recebiam um litro de leite por dia para as crianças e, no final de semana, meu pai trazia um sabão, querosene e sal, umas coisas básicas. Isso era o pagamento. Em troca, a família inteira trabalhava, desde criança de seis, sete anos de idade, até os adultos, que trabalhavam tanto vinculados ao gado - meu pai criava gado - quanto nas tarefas agrícolas. 
A fazenda do meu pai era o tipo de consórcio característico do Sertão do Nordeste, de pecuária e agricultura de subsistência. Meu pai tinha cerca de 300 hectares de terra, era classificado como um latifúndio por extensão, mas na verdade teve uma vida muito simples. Meu pai conseguia se manter porque ele explorava esse subtrabalho de forma intensa, mas também explorava o trabalho dos filhos. A minha infância acabou aos sete anos de idade, eu não tive mais infância a partir disso. Fui trabalhar todos os dias, ou no gado ou no roçado. Acordava normalmente as seis horas da manhã, tomava café e começava, a partir das sete da manhã, a trabalhar. Parava para o almoço - a gente almoçava em torno das nove horas da manhã - depois a gente parava para jantar ao meio-dia, depois parava em torno de cinco horas da tarde. Isso era o tempo todo.

Valéria. Todos os filhos?

Durval. Todos os filhos. A gente limpava mato, plantava, levava o gado para beber. Às vezes no verão não tinha água perto, então a gente andava quilômetros. Tirava o leite do gado em torno de sete horas da manhã, aí saia e chegava meio-dia, uma hora da tarde, tangendo esses gados pelas estradas para uma cacimba, para um poço que ficava em uma outra propriedade. No caminho, a gente ia encontrando vários outros rebanhos que iam sendo levados para o mesmo lugar, então muitas vezes as vacas pegavam, os touros brigavam, se misturavam, era um pandemônio. A gente levava também um jumento com curetas, que são reservatórios para trazer água para casa.

O gado só bebe uma vez por dia, tinha que guardar a sede pro outro dia. Eles bebiam nessa hora que chegavam lá, o que significava um trabalho muito pesado também porque era um cocho de cimento que tinha que 
encher com a água que tirava do poço e deixar cheio, já que a gente chegava e já estava cheio. A vaca bebia aquela água toda e a gente tinha que encher para a próxima pessoa que chegasse não encontrar o cocho vazio.

Daisy. E a vida escolar, começa quando?

Durval. Não havia escola na região, então eu fui escolarizado pela minha mãe, ela que me dava aula, normalmente à noite. Sou escolarizado até o quarto ano, por ela. Depois, eu fiz o exame de admissão ao ginásio, estudei durante um ano, um livrão enorme assim, para o exame de admissão do ginásio. Fiz um teste que parecia o vestibular, é um minivestibular, para começar o que se chamava na época de ginásio, que era a segunda fase do Ensino Fundamental. Aí eu passei a viajar toda noite de Jeep, tinha um Jeep do vizinho lá de casa. Em torno de quatro horas da tarde, eu parava, acabava o serviço, tomava banho e jantava às cinco horas da tarde. Aí eu saia, a gente pegava o carro às seis horas e se deslocava por cerca de uma hora de casa, na estrada de terra, para a cidadezinha de Boqueirão, onde eu fazia o segundo grau no Colégio Comercial. A escola se chamava Padre Inácio, colégio ligado à rede cenecista, uma rede de colégios.

Valéria. Era um colégio privado?

Durval. Era um colégio que a gente pagava mensalidade, mas era comunitário, uma instituição comunitária. Aí eu fiz o segundo grau, a segunda fase no caso. Eu só mudei para a cidade para fazer o segundo grau.

Quer dizer, a minha experiência de sertão, as minhas imagens do Nordeste nascem dessa convivência muito direta com a terra, com a 
pecuária, com essa miséria enorme. Os moradores do meu pai não tinham nada, absolutamente nada. Eles tinham algumas redes... E, quando muito, tinham um banco de madeira rústico, um prato, uma colher, era uma miséria completa.

Daisy. E a sua casa, como era o espaço, como que ele se constituía? Você tinha um quarto só para você ou era com os irmãos?

Durval. Eu dividia com meus irmãos homens. A casa era bastante grande, inicialmente não era rebocada, era de tijolo aparente, mas já bem grande. Tinha uma sala enorme com umas quatro ou cinco janelas, aquelas janelas imensas que dão para o terreiro. Tinha uma sala de jantar bastante grande. Paralelos à sala de jantar, você tinha os quartos: o quarto do casal, o quarto dos filhos e atrás tinha cozinha, do lado uma despensa. Lá atrás do terreiro ficava o banheiro, que era fossa direto no chão, tinha vaso sanitário, mas não descarga, tinha que dar descarga com o caneco.

Valéria. Essa casa ainda está lá?

Durval. Essa casa ainda existe, meu irmão mora nela hoje, mas está caindo aos pedaços. Ela era uma casa que depois foi toda pintada, rebocada, passou a ser cor-de-rosa, enorme! Um rosa meio colonial, de janelas verdes... Verde e rosa. $\mathrm{Na}$ sala da frente, por exemplo, se usava muito para guardar mantimentos, colocar algodão, colocar milho e tal. Depois, ela foi dividida, aí o quarto do casal foi feito nessa metade da sala.

Valéria. O banheiro continuou ali?

Durval. Continuou aí porque precisou minha irmã ter um quarto só para ela porque ela cresceu e não podia estar misturando com os irmãos, não é? Houve um momento em que o curral das vacas era vizinho à casa, era cercado. As janelas do quarto davam para o curral, davam para o coxo 
onde as vacas ficavam comendo, então a gente se debruçava na janela coçando a cabeça das vacas (risos), que ficavam comendo ali. Depois, meu pai soube que não era bom higienicamente aquilo e deslocou o curral para a parte de baixo. Depois da casa tinha um terreiro na parte de baixo que passou a ser o curral das vacas. Quando comprou o motor para moer capim, o motor onde eu perdi a minha mão, foi construída uma casa lateral, onde se colocou esse motor. Foram todos os avanços tecnológicos que se teve durante muito tempo na fazenda.

Então, criar gado naquela região onde papai criava, era assim: você carregava nas costas o rebanho durante seis meses. O que você ganhava no primeiro semestre, gastava no segundo porque tinha que vender os bezerros que tinham nascido, os garrotes para comprar ração, porque o gado era sustentado por ração. Tinha a palma forrageira, que é uma planta xerófita típica lá do Nordeste que se planta para dar para o gado. Mas a palma forrageira provoca muita disenteria, se você não der junto algum tipo de farelo. Então, meu pai tinha que comprar o farelo que era feito da semente de algodão, que se comprava na cidade de Campina Grande. A nossa relação toda era com a cidade de Campina Grande.

Papai fazia feira todo final de semana indo para lá em cima de um caminhão que levava porco, galinha, saco de milho para vender. Várias vezes, viajei para cidade assim, junto com ele. Ia parando nas várias cidades. Na volta, vinham as caixas com a feira, sacos e as caixas de madeira com a feira. Meu pai tinha uma caixa de madeira enorme, onde vinham os mantimentos. Eu costumo dizer que as minhas primeiras experiências eróticas foram esses movimentos (risos). Foi ir para feira com meu pai e tomar café da manhã nos bares da feira, onde as prostitutas 
eram as garçonetes. Então, as prostitutas trabalhavam à noite e, durante o dia, elas eram garçonetes das lanchonetes. Elas ficavam sendo cantadas pelos caras, sendo alisadas, os caras passavam a mão nelas. Aquela foi a primeira vez que me dei conta dessa coisa, foi aos seis, sete anos de idade, meu pai me levando para esses lugares.

Normalmente, eram corredores muito estreitos. As mesas distribuídas por aqueles corredores e ali a gente comia cuscuz, macaxeira, bolo porque saia muito cedo. O carro saia em torno de quatro horas da manhã, quando chegava em Campina Grande era em torno de sete, então você tinha que tomar café para ir fazer a feira. Campina Grande até hoje é uma grande feira livre, vende de tudo que você possa imaginar: de passarinho a fumo de rolo, produtos de cerâmica de barro, roupas, carnes, vegetais, frutas, queijo, doce. Tudo que você possa imaginar tem na feira de Campina Grande, ali é um mercado enorme, que fica no centro da cidade. Foi aí que eu trabalhei mais à frente, quando escrevi a Feira dos Mitos, por isso o nome Feira dos Mitos. É uma homenagem à minha época de feira.

Quando eu fui fazer o segundo grau, quando fui para a cidade para fazer o Ensino Médio, aí que fui trabalhar na feira, porque meu pai não dispensava a gente, tinha que trabalhar com alguma coisa: quartas-feiras, sextas e sábados, que eram dias de feira. Eu revendia o queijo que ele produzia na fazenda em um banco na feira, que ficava em frente à feira de doce. Era maravilhoso, passava o tempo todo comendo doce, queijo, aqueles tabletes enormes de doce de jaca, de mamão, goiaba. E lá também eu via muita miséria. Feira é um lugar de muita miséria, um lugar de prostituição, lugar de exploração do trabalho infantil. Existia uma figura que sempre me impressionou muito, que era a figura do balaieiro ou do 
cabeceiro. Era uma pessoa que vinha com o balaio e que era contratada por uma madame, que ia comprando as coisas e colocando dentro daquele balaio na cabeça da pessoa, quase até enterrar o pescoço dele. Eram normalmente pessoas negras ou pardas, geralmente muito mal vestidas, às vezes só farrapos como roupas, normalmente descalços, os pés muito rachados. Depois do balaio completamente cheio, a madame pegava o carro e ia para casa. Essa pessoa ia a pé levar na casa dela a feira na cabeça para ganhar o equivalente ao que seria hoje dois reais, um real, dois reais. Eu estudando história, lendo sobre a escravidão, via as cenas reais da escravidão. A feira era um lugar de muita prostituição, a zona do baixo meretrício ficava dentro da feira, quer dizer, as prostitutas mais pobres, as prostitutas que justamente atendiam a essas pessoas que vinham dos sítios, que vinham das fazendas. Eram mulheres muito cheias de manchas na pele, doenças, claro, muitas doentes, claramente. Muito menino pedindo, pessoas inclusive com aquela doença de São Guido, que a pessoa treme o tempo todo e baba. Tinha uma pessoa que me impressionava, porque ele tinha queimado grande parte do rosto, a boca dele era completamente aberta, ele babava o tempo todo e passava pedindo as coisas. Então, a feira era esse lugar que, ao mesmo tempo de muita fartura, tinha muita miséria.

Daisy. E você é muito observador. Sempre foi assim? Você é um etnógrafo, não é? Tudo o que você vê, você observa, não tem nada que você desperdice...

Durval. Dizem que os cancerianos são assim (risos)... Mas eu sempre fui muito observador, sou uma pessoa caracteristicamente observadora. 
Normalmente, gosto de ficar nos lugares meio retirado, observando. Depois, eu sei dizer tudo, então sou um grande observador.

Então, eu tenho todas essas experiências. Passei um ano na casa da minha madrinha em Campina Grande entre, entre 12 e 13 anos, o meu sexto ano foi feito em Campina Grande. Foi tentativa de deixar de viajar e viver com a minha madrinha que morava em Campina Grande e que era dona de uma pensão masculina. Aí, evidentemente, eu vivenciei as primeiras experiências sexuais homoeróticas porque meu primo era gay e eu dormia no mesmo quarto que ele. Algumas vezes, os namorados pulavam a janela e eu escutava todo o movimento debaixo da coberta. Não entendia muito bem aquela situação, mas sabia que alguma coisa estava se passando ali.

Existia uma vizinha da frente que era lesbiana. Não sei por que, eu sempre atrai a capacidade das pessoas me dizerem os segredos mais íntimos. Então, um guri de 11 anos, 12 anos, virei o leva e traz recado para namorada. As confissões dos dramas... Entendeu? Eu já me ambientei, no momento em que eu estava ainda tendo minhas primeiras experiências em termos de leitura.

$\mathrm{Na}$ fazenda, qual foi a primeira coisa que eu li na vida? Foi a bíblia inteira. Os meus pais eram muito religiosos, muito católicos, te contei, né? Que eles se encontraram na igreja de Moema, se conheceram na igreja de Nossa Senhora de Aparecida e se casaram lá. Eu dizia para eles: "vocês iam para missa para namorar" (risos). Eles sempre foram muito católicos, a minha casa era cheia de santos nas paredes, até uma imagem de Frei Damião, que nunca foi santificado inclusive, tinha lá na parede. $\mathrm{Na}$ Semana Santa, viravam todos os quadros para a parede, cobriam todos de 
pano preto. A gente ouvia aqueles programas no rádio, a narrativa de passagens bíblicas, o tempo todo.

$\mathrm{O}$ rádio foi uma coisa muito importante para mim. Acho que essa minha capacidade de narrar e de imaginar tem a ver com o rádio. Minha imaginação foi educada pelo rádio, não foi educada pela TV, não foi educada pelo cinema, não foi educada por nada que ofereça imagens. Eu tinha que imaginar todas as coisas. Quer dizer, o mundo externo chegava para mim era através do rádio. Em Campina Grande, naquela época, a gente pegava três estações de rádio AM: a Rádio Borborema, Rádio Caturité e a Rádio do Cariri. A Rádio Caturité é uma rádio da igreja católica. E tinha as duas outras rádios que eram dos diários associados, que era Assis Chateaubriand, a Borborema e a Cariri.

A Rádio Cariri era uma rádio que investia muito na música, eram programas musicais quase sempre, música quase o dia inteiro. A Rádio Borborema tinha um perfil das rádios dos anos 40 e 50, de ter shows, de ter auditório. Tinham coisas que as pessoas não acreditam. Por exemplo, os desfiles de carnaval eram narrados pela rádio e eu ficava ouvindo e imaginando a escola de samba desfilando porque eles narravam as alegorias, as fantasias, as alas. Eles iam para os clubes e transmitiam os bailes e eu ficava viajando nos bailes. Como se você estivesse lá! Nossa mãe fazia fantasia e a gente ficava em volta do rádio. Ela era fantástica e alimentava muito a nossa imaginação. Nossa mãe foi uma grande narradora. Eu conheço de nome boa parte dos grandes nomes do cinema dos anos 30, 40, 50 porque minha mãe narrava. Quando eu vi pela primeira vez E o Vento Levou, eu já sabia, era como se fosse um déjà-vu porque minha mãe narrou mais de uma vez. O Morro dos Ventos Uivantes, 
todos os grandes clássicos do cinema dos anos 40 e 50. Quando ela vivia aqui, ia ao cinema todo final de semana, ela adorava cinema, então contava. Esses atores todos: Greta Garbo, de Vivien Leigh, de Katharine Hepburn, Clark Gable... Eu ouvi falar em todas essas criaturas muito antes de ter visto a cara de qualquer um.

Daisy. Como ela contava estas histórias, tinha um ritual? Todas as noites, ela sentava...

Durval. Quase sempre, todas as noites. À noite, a gente não tinha nada para fazer, não tinha televisão. Tinha pronunciamento na hora da $V o z$ do Brasil, que ninguém escutava. Então, ela ficava contando, colocava a gente no colo e eu ficava em volta dela. Na verdade, ela tinha um enorme prazer em lembrar dessa época da vida dela, era uma coisa também dela um pouco reviver isso. Para vocês terem uma ideia, a primeira vez que eu vim a São Paulo, andei em alguns espaços que ela narrava e era como se eu já tivesse estado ali. A primeira vez que eu fui ao Vale do Anhangabaú, a primeira vez que eu fui a Galeria Prestes Maia... A minha mãe narrou isso 500 vezes! Era igual e não era, havia traços do que eu havia imaginado, a medida em que ela narrava.

A primeira vez que eu vim a São Paulo foi em 1968. Foi um ano de uma colheita excepcional de algodão, a gente colheu muito algodão. Conseguimos ganhar um bom dinheiro e meu pai prometeu que traria minha mãe, depois de quase dez anos, para ver a família dela. Minha mãe tinha chegado lá em 1958 e nunca mais tinha vindo ver a família. A gente veio em um ônibus de uma empresa local na época, era a Empresa Nacional de Luxo. Viemos em 54 horas de viagem. 
De Campina Grande não é uma coisa fácil. No Rio São Francisco não tinha ponte, esperamos quase cinco horas para atravessar a balsa e, em volta ali da balsa, aquela montanha de caminhoneiros de todos os lugares do Brasil. Chimarrão, churrasco, conversas de vários tipos, muitas baianas vendendo acarajé, vendendo coisas. Eu era criança e foi uma diversão, não queria mais ir embora! Queria brincar na beira do rio, foi uma tristeza quando a balsa chegou. Aqui em São Paulo, papai fez a gente passar cada mico histórico! Meu pai fez a gente se ajoelhar e rezar para o Padre José de Anchieta no Museu do Ipiranga! (risos) Meu pai fez a gente passear pelo Minhocão, os carros quase levaram a gente! (risos) Foi coisa de matuto mesmo, de caipira. Foi quando eu conheci São Paulo. A primeira vez que eu cheguei em São Paulo, a primeira sensação foi de muito medo, a zoada da cidade, o barulho da cidade me causou um... Me impressionou profundamente. É que eu morava no mato, não estava acostumado com essa sonoridade, com essa coisa, parecia um monstro rugindo, a cidade.

Daisy. E tua mãe sobreviveu bem a esse deslocamento?

Durval. Minha mãe sofreu muito. No primeiro ano ela chorava quase o ano inteiro...

Valéria. Ela era uma mulher urbana, não era?

Durval. É, ela era uma mulher urbana, ela era uma mulher que ela era secretária dos Laboratórios Arnoud. Era uma mulher que tinha feito formação de Ensino Médio técnico, para a época era uma coisa bastante avançada para as mulheres. E meu pai era um cozinheiro da Beneficência Portuguesa. Minha mãe foi quem comprou grande parte das coisas quando eles casaram, a família dela não queria o casamento. Quando chegou lá foi o inverso: minha mãe mal chegou, ouviu o meu avô fazer a 
seguinte pergunta: "bem, você arrumou essa mulher que não é da família, mas, pelo menos, ela trouxe alguma cabeça de gado? Com quantas cabeças de gado ela veio?”

Eu acho que o rádio foi muito responsável por eu ter desenvolvido tanto a imaginação, eu gostava tanto de rádio que minha mãe me deu como presente um radinho de pilha. Eu andava por todo lugar com ele. Eu ia tangendo cabras, os rebanhos, ia pro roçado e levava o radinho de pilha aqui no bolso, ouvindo...

Daisy. O que é que você ouvia?

Durval. Sempre gostei muito de música, sempre gostei muito de ouvir futebol. Futebol narrado pelo rádio não tem igual, é outra coisa. Me lembro da Copa de 1970, o jogo Brasil e Uruguai que eu fiz xixi nas calças de tão nervoso (risos), quando fez um a zero, uma tristeza!

Valéria. Que músicas você lembra dessa época?

Durval. Por exemplo, os Beatles, os Rolling Stones... Eu fiz uma guitarra de pau para tocar. Aliás, levei uma surra com a guitarra porque inventei de, na hora que estava almoçando (que era uma hora sublime que todo mundo tinha que ficar em torno do pater família), eu resolvi sair da mesa intempestivamente para ir tocar na beira do rádio a minha guitarra, aí voltei para mesa e apanhei com a própria guitarra. Música, é claro, o baião é dessa época. Toda manhã a gente acordava ouvindo os programas de música do Luiz Gonzaga, Trio Nordestino, Marinês, Genival Lacerda, Jackson do Pandeiro, todos esses grandes nomes, tocavam logo cedo.

Valéria. Não era uma música especificamente da Paraíba, então?

Durval. Não

Valéria. Era já essa música do "Nordeste”? 
Durval. Sim, eram programas já inclusive nomeados de música nordestina.

Valéria. E eram programas de rádios daqui do Sudeste ou de lá?

Durval. Não, eram rádios de lá, as rádios do Nordeste nos anos 50, 60 elas têm inclusive programas de auditório de onde vêm todos esses artistas. As rádios de Campina Grande são rádios que lançaram muito dessa gente, Marinês começou em Campina Grande, Sivuca começou em Campina Grande.

V. A Marinês é que era esposa do Sivuca?

D. Não, ela era esposa do Abdias, que era um exímio tocador de fole de oito baixo, que só gravava música instrumental. Então, ela começou em Campina Grande, vários passaram por lá, o Jackson tem várias músicas sobre Campina Grande, é um grande centro de produção de cordel e também de cultura popular de uma forma geral, por causa da feira, por ser uma cidade de imigração, é uma cidade de migrantes de todos os lugares, que recebem grande parte da migração do sertão, é uma cidade que fica no começo da área úmida chamada agreste. Nos anos 40, foi o grande centro exportador de algodão da região, o algodão vinha do sertão, era beneficiado em Campina Grande e exportado no porto em Recife para Inglaterra, Estados Unidos. A cidade teve uma acumulação tão grande de capital nos anos 40, que teve um banco próprio, um banco de uma família, o Banco Industrial de Campina Grande chegou a ter filiais em São Paulo, Rio de Janeiro. Foi a primeira cidade que teve uma estação de televisão na Paraíba, antes da capital. Tinha uma companhia de esgoto própria, uma companhia de água própria, companhia de energia elétrica própria. A energia elétrica só foi privatizada no governo Fernando 
Henrique, era uma companhia de uma cidade e de uma região. Era tão específica que como tinha uma rede pequena, ela podia desligar toda passagem de ano. Então, toda passagem do ano em Campina Grande era marcada: na hora que dava meia-noite, a cidade inteira ficava no escuro. Ela era apagada e cinco minutos depois voltava, podia fazer isso porque não era uma rede grande integrada, era uma rede própria. Era um marco isso para a cidade, a gente ficava no escuro se abraçando, fazendo integração (risos).

Valéria. Durval, em que ano você nasceu?

Durval. Eu nasci em 1961.

Valéria. Que dia que você nasceu?

Durval. Eu nasci no dia 22 de junho, dois dias antes de São João.

Valéria. Então você é canceriano?

Durval. Mas eu sou como Luiz Inácio da Silva, eu tenho duas datas de nascimento porque meu pai me registrou errado, me registrou no dia 20 de junho.

Daisy. Ah, então você não seria canceriano?

Durval. Aí eu não seria canceriano, exatamente.

Daisy. Seria geminiano.

Durval. Mas foi um erro dele porque se registrava depois.

Valéria. Acontecia bastante. Você comemora seu aniversário no dia 22?

Durval. No dia 22, normalmente eu vou para Campina Grande quando está fervendo o São João. A festa está pronta, eu não preciso fazer festa. 22, 23, 24 são o auge da festa. É porque o dia 24 é o dia de São João, 23 é a véspera, 22 é antevéspera. É normalmente o grande momento. São João é tão grande! Normalmente, eu vou para lá, porque estão todos os meus 
familiares, meus amigos estão lá. Muita gente volta nessa época, muita gente que está fora tira férias neste mês, então eu encontro muita gente.

Daisy. E teus irmãos ficaram lá?

Durval. Eu tenho um irmão mais velho só aqui em São Paulo, mas os meus irmãos mais novos estão todos lá na Paraíba. Tenho uma irmã e um irmão e tenho mais três com a outra esposa do meu pai.

Valéria. Mais jovens, né?

Durval. Mais jovens. Duas meninas moram já na cidade de Campina Grande e o rapaz mora na fazenda, o que herdou a fazenda, é o que está lá com a casa caindo mesmo aos pedaços.

Valéria. Esse seu irmão que mora aqui, ele chegou a morar lá também, né?

Durval. Sim.

Valéria. Ele foi e voltou?

Durval. Sim, ele foi algumas vezes e voltou, tentou algumas vezes. É o filho primogênito, muito parecido com a minha mãe. É estranho, eu sou o segundo filho e sou eu que tenho o nome do meu pai, sou eu que levo o nome de "Júnior", mas deveria ser ele. E justamente eu sou o que parece com meu pai, eu sou o único loiro de olho verde.

Valéria. Você se parece fisicamente também?

Durval. É, meus irmãos se parecem comigo, mas eles são mais morenos porque minha mãe era descendente de indígena. Minha avó materna era completamente indígena, minha bisavó tinha sido caçada no mato pelo meu bisavô, lá no interior de São Paulo. Então, a minha avó - a filha deles - era filha de um português com uma índia "apresada" no mato. A primeira vez que eu vim a conhecer minha avó, lá em Jales, a primeira 
imagem que eu tenho dela, ela estava de costas. O que me impressionou foi o cabelo enorme, liso, imenso, batendo lá embaixo na cintura. Cabelo de um vigor, de um brilho! Era um belíssimo cabelo o dela. Uma mulher muito própria. Ela tinha uma relação de ajuda com quase todas as prostitutas da cidade, criou vários filhos de prostitutas, teve mais de 12 filhos de criação de prostitutas da cidade. Eu fui bater no meretrício de Jales com ela. Foi como uma das minhas experiências. De charrete, era uma cidade que todo mundo andava de charrete ainda, toda de terra vermelha.

Daisy. Você falou da sua mãe, está falando da sua avó, pelo visto a sua linhagem materna das mulheres é muito forte e todas muito singulares.

Durval. Eu dizia ontem que meu grande modelo é minha mãe. Eu nunca tive nenhuma identidade com meu pai porque ele era um homem muito violento, um pai muito difícil. Eu acho que, depois eu compreendi, meu pai era muito inseguro, em relação a cumprir essa figura paterna, a não falhar nessa paternidade. Ele tinha medo que os filhos se perdessem, que não trabalhassem, tinha uma verdadeira obsessão com essa história de trabalhar.

Eu perdi essa mão já cursando o Ensino Médio em Campina Grande, fui passar o final do ano, o natal, com eles na fazenda e meu pai me bota pra moer capim. Aí eu vou muito revoltado, chorando e aí perco a mão! A máquina pega a ponta da luva que eu estava usando e leva. Aí ele mudou muito a partir daí.

Daisy. Eu imagino que tenha sido um acontecimento muito traumático. Durval. Foi, mudou muito.

Daisy. Muito traumático para a família inteira. 
Durval. Foi, ele se sentia culpado, então mudou muito. Já foi um pai bem melhor para os filhos outros que teve, foi meio um pai avô, um pai muito mais carinhoso. Para mim mesmo ele se tornou um pai muito mais próximo. Por exemplo, quando eu contei sobre a minha homossexualidade, ele reagiu muito melhor do que minha mãe. Ele nunca teve nenhum preconceito, inclusive em relação aos meus companheiros, se tornou uma pessoa bem mais... Durante muito tempo, o dia que a gente mais gostava na semana era o sábado, que meu pai não estava em casa. Ele ia para a feira e não estava em casa, era o dia que a gente esperava, ao longo de toda semana, era meu pai ir embora.

Valéria. Ele passou por uma transformação, não foi?

Durval. Muito grande.

Valéria. E foi por causa do acidente com seu braço?

Durval. Eu acho que sim, acho que foi. Teve também depois a história da doença de minha mãe e a morte dela, isso também mudou muito. Ele amava enormemente minha mãe. Depois que ela morreu, meu pai não falava de minha mãe para não encher os olhos d'água. Foi uma história de amor belíssima. Eu sou filho de uma história de amor muito bonita porque também o que minha mãe sacrificou na vida por causa desse amor foi uma coisa inacreditável. Você sair de uma cidade como São Paulo, deixar de ser secretária executiva para ir limpar tacho de fazer queijo, não é? Em uma fazenda, em uma casa que quando ela chegou era terra de chão batido e o batente era um pedaço de pau que rolava, então assim... Valéria. Ela reclamava? 
Durval. No começo reclamava, acho que reclamava muito, mas eu já a conheci muito adaptada na verdade. Ela tinha uma boa relação com a vizinhança e trabalhava muito. Minha mãe dedicava-se muito ao trabalho.

Valéria. E era um trabalho na roça mesmo?

Durval. É um trabalho de casa, basicamente ajudar meu pai na história do queijo, era ela que colocava a água no leite para coalhar, era ela que ajudava ele a colocar os queijos em um...

Daisy. Mas ela dava aula, não é?

Durval. Em um determinado momento ela resolveu fazer isso, durou uns dois anos porque meu pai logo sabotou. Não deixava ela ficar nem com o dinheiro dos ovos da galinha, aliás ele vendia e ficava com o dinheiro. Ele temia demais a independência dela porque ele era semianalfabeto e minha mãe poderia escapar para qualquer lugar. Meu pai tinha muita insegurança em relação a ela e minha mãe era uma mulher de opiniões muito fortes. Então, se ela resolvesse ir embora, meu pai não teria como impedi-la. E teria para onde vir, com a família dela para cá. Evidentemente, todos que foram contra o casamento inclusive, estariam dispostos a trazê-la, a recebê-la. Ele sempre teve essa insegurança. Aí, claro, o que é que ele tinha de vantagem? Toda a questão financeira na mão, minha mãe não tinha como sobreviver. Mas eles se gostavam bastante, mas meu pai sempre brigava com ela, quase sempre por causa de dinheiro, porque ele era muito pão-duro, quando ela precisava de alguma coisa, quase sempre saia uma briga. Para a gente ir para Campina Grande estudar, ela ameaçou ir embora, abandoná-lo, se ele não alugasse uma casa em Campina Grande para gente estudar. Ela ia embora para gente estudar em São Paulo. Em um instante, alugou. 
Daisy. E para você foi uma solução importante?

Durval. Muito grande, eu lembro até do cheiro dessa madrugada chegando em Campina Grande. É uma coisa tão significativa o cheiro daquela madrugada, daquela manhã, jamais saiu das minhas narinas. E eu fui morar em um bairro significativo chamado Liberdade, foi o que significou para mim. Odiava aquela vida da fazenda, por isso sempre estudei muito, eu gostava até do cheiro dos livros. Papai comprava os livros didáticos e eu adorava aquele cheiro de cola, achava tudo muito lindo, as figuras, as letras, tudo. Para mim, o mundo das letras sempre foi encantador e eu sabia que aquilo ali era minha única chance de sair dali. Então eu investi sempre muito nisso.

Daisy. E a literatura apareceu cedo também, nesse momento?

Durval. Não porque justamente não tinha tempo, a gente trabalhava o tempo todo. Durante muito tempo, eu tive uma defasagem enorme em termos de conhecimento da literatura brasileira, de autores brasileiros. Daí porque essa tese foi fundamental, eu parar quatro anos, e me obriguei a ler tudo. Eu ainda não conheço autores de literatura internacional fundamentais, por quê? Porque não tinha tempo, a gente trabalhava o dia inteiro e a noite estudava. Quando eu vim para Campina Grande, trabalhava e estudava também porque no Ensino Médio você tinha as aulas pela manhã, três vezes por semana, educação física à tarde. Eu tinha que colocar esses dias nos dias que não coincidiam com a feira porque eu tinha que estar quarta, sexta e sábado na feira. Eu ia normalmente segunda, terça e quinta na educação física e aí só ficava à noite. Aí fascinado pela televisão, já morando em uma cidade, à noite a gente assistia televisão. Até porque era um momento em que a televisão 
brasileira valia a pena de assistir (risos). Por exemplo a gente via o programa do Chacrinha que eu amava. Mesmo o programa do Silvio Santos, que durava o domingo inteiro, era uma atração. O Flávio Cavalcante e as grandes novelas, as minisséries...

Daisy. O Bem Amado você assistia?

Durval. Assistia O Bem Amado, assistia como minissérie, muito eu acompanhei.

Valéria. Durval, quando que você começou a entender que você gostava de História, especificamente?

Durval. Foi a partir do Ensino Médio, com a Marta Lúcia Ribeiro, minha professora, que me marcou muito pela forma com que dava aula, como ensinava História.

Valéria. Só para eu entender: ela era professora de História mesmo?

Durval. Ela foi minha professora de História durante meus três anos do Ensino Médio, no mesmo colégio estadual.

Valéria. Já não é mais aquele primeiro colégio que você citou...

Durval. Não, era um colégio já em Campina Grande que eu ia a pé toda manhã e que lembro também de todos os cheiros, que Campina Grande é uma cidade cheia de cheiros, notadamente de árvores castanholas, cheira muito castanhola. Ela era muito diferente porque ela ensinava de uma forma diferente a história, não era aquela forma de memorização. Marta partia muito das questões que estavam acontecendo no momento, era uma mulher de esquerda. A gente estava vivendo, naquele momento, um processo de abertura política.

Valéria. Era a década de 1970? 
Durval. Era. Ela tinha acabado de desenterrar a biblioteca dela. Ela teve que enterrar a biblioteca no quintal, em uma espécie de cisterna, no Golpe de 64. Então, ela emprestava aqueles livros meio amarelados, meio mofados, aquilo era uma coisa fantástica! Livro que sobreviveu à Ditadura (risos). A primeira grande crise lá em casa com a minha mãe foi quando me pegou lendo $A$ Ilha, de Fernando Morais. Foi uma crise enorme porque minha mãe católica: “esse livro é comunista”. Na verdade, eu fazia parte de grupos de igreja, de jovens da igreja. Minha formação política também foi toda feita pela igreja católica progressista.

Eu cantava no coral da igreja, sempre adorei ficar lá na frente, sempre gostei de aparecer (risos). Quando eu morei esse ano na casa da minha madrinha, que eu era um guri de sete, oito anos de idade, eu adorava balançar o sino para o padre só para sentar naquela cadeira de veludo vermelha. Ficava lá no altar, então ficava toda a igreja voltada para mim e eu sentado lá naquela coisa de veludo vermelho, sempre gostei de aparecer! (risos) Sempre fui um artista frustrado, professor é um pouco artista, não dei para cantar...

E aí eu tive toda essa formação, os padres redentoristas, era época de muitos movimentos sociais na cidade, ocupações e as igrejas participavam dessas ocupações. A cidade em um crescimento muito grande, as favelas. Aí eu me formei e Marta estava muito ligada a isso. Existia outra professora, de OSPB, na época Organização Social e Política do Brasil, que também era uma moça de esquerda, a Joana, que foi quem emprestou A Ilha para mim, encapado com uma capa parda para ninguém ver o que era. Foi isso que chamou a atenção da minha mãe, o danado do livro 
misterioso encapado. Acho que ela achou que eu estava lendo algum livro de sacanagem. Quando ela foi ver, era $A$ Ilha, Fernando Morais.

A minha mãe era muito controladora, muito dominadora eu tive muitas dificuldades de lidar com as chantagens emocionais dela, mulher faz muita chantagem emocional, mãe faz muita chantagem. Se a gente sobrevive à mãe, a gente sobrevive a tudo. Se eu chegasse um pouco mais tarde, ela estava no escuro na sala. Quando eu entrava, ela estava tendo problemas respiratórios (risos): "você vai me matar", ofegante. Aí eu passava mais uns três meses sem sair de casa, porque quem é que vai carregar a culpa da mãe morrer, sufocada no meio da noite, por sua causa?

Daisy. Mas ela não viu todo esse seu crescimento? Ela morreu precocemente, não foi?

Durval. Morreu. Ela me viu entrar na universidade, ser professor, na verdade ela morreu na passagem do mestrado para o doutorado. Viu sim, claro. Meus primeiros salários foram todos gastos com ela, dei televisão nova e durante muito tempo não pude dar a meu pai, que morava em uma fazenda onde sequer tinha energia elétrica. Fui poder fazer isso pro meu pai no Governo Luís Inácio Lula da Silva, quando o Luz Para Todos colocou luz na terra dele. Aí ele passou a ter o conforto que ele poderia ter porque mudou completamente de vida. Meu pai era uma pessoa extremamente conservadora, sempre teve muito medo de Lula, muito medo da reforma agrária. Eu ficava brincando: "papai quem é que vai querer dividir essas suas terras seca aqui, nem de graça alguém quer”. Eu morria de rir. Quando o Lula foi eleito, que veio o Luz Para Todos, depois veio o programa do leite (ele vendia o leite a 40 centavos e passou a vender a 70 centavos) para o programa de alimentação para merenda 
escolar. Ele recebeu um curso, uma cisterna, daquele programa de cisterna...

Valéria. Um Milhão de Cisternas?

Durval. É, Um Milhão de Cisternas. Depois, veio o programa de plantar mamona para fazer biodiesel, onde a Petrobrás distribuiu sementes para se plantar mamona.

Valéria. E ele ficou morando no sítio, até o final da vida dele?

Durval. Até morrer. O meu pai, na reeleição de Lula, a primeira vez que se deslocou da fazenda para ir em um comício foi para ver Lula em Campina Grande, chorou o comício quase todo. Foi completamente transformado. Com aquele jeito dele: “isso que é um presidente macho". Brigava com meu irmão mais velho, que é um malufista, meu pai passou a brigar.

Daisy. E Durval eu ia te perguntar dessa sua relação com esse espaço do Nordeste. Se essas relações com essa sonoridade, com essa sensorialidade, com esta afetividade, a gente não está falando dos estereótipos, mas de sensação corpórea, se ela é fundamental...

Durval. Sim, eu não me conheço, não me percebo fora do Nordeste. Recebi muitos convites, passei períodos fora do Nordeste, não foi nada traumático. Não sou uma pessoa que sofro quando saio dos lugares, ao contrário: me adapto super bem. Sinto falta de pessoas, não de lugares, me adapto muito bem. Passei um ano maravilhoso em Barcelona, nunca sofri porque estava com saudades do Brasil, nem me lembrava. Em Lisboa... Vivi em Campinas também, aproveitei. Mas o Nordeste tem um significado muito grande para mim, não é mera coincidência que eu estudo o Nordeste. É porque me incomoda a forma com que o Nordeste 
é visto, é pensado, é tratado. Claro que isso não significa vitimização porque eu sei, mais do que ninguém, que essa imagem foi criada pelos próprios nordestinos, pela própria elite nordestina que faturou com essa imagem, que viveu da miséria, da exploração da miséria, da exploração dessas imagens. Quer dizer, a elite nordestina conseguiu recursos, conseguiu obras, conseguiu investimentos, conseguiu sinecuras políticas, cargos, a partiu desse chororô regionalista, desse discurso do coitadismo, que é vítima da exploração. Eu não entro nessa conversa, nunca entrei. Mas o Nordeste tem uma significação muito grande por causa que é meu território de existência. A diversidade que é aquilo, a riqueza que aquilo em termos de produção cultural mesmo. Eu conheço esse Nordeste por dentro, não só por morar no mato, ou viver essas experiências que eu vivi, mas por andar muito pelo Nordeste. Eu viajo muito no Nordeste, eu sei as transformações que ele sofreu nos últimos anos. É por isso que me indigna tanto.

O Nordeste mudou completamente, as casas de taipa desapareceram, a paisagem do Nordeste se encheu de cisterna para todo canto. As estradas se asfaltaram, a noite no Nordeste praticamente acabou, é iluminada de tal forma que você pensa que é uma cidade, que você não pensa que está passando em uma zona rural. Cada casa tinha uma luzinha na porta, cada casa rural tem lá sua luz no terreiro, basta sobrevoar o Nordeste para você ver a diferença. A transposição, o que significou aquela chegada da água em Monteiro? Eu estava lá, ninguém tem ideia da emoção que foi aquilo, uma cidade de 40 mil pessoas tinha 100 mil... A cidade estava entupida. A gente deixou o carro a dez quilômetros da cidade, teve que andar a pé 10 quilômetros porque o carro não chegava mais lá. Quando o Lula e Dilma 
chegaram, era uma coisa assim: parecia que as pessoas queriam amassar eles. Se não tivesse segurança amassavam eles, o amor, a loucura. Por onde ele ia passando, as pessoas iam parando. Ele levou horas para chegar e queria entrar na água. Não teve jeito do povo deixar, ele entrou depois, não resistiu, botou a bermudona vermelha e entrou na água, tomou um banho, teve inclusive umas fotos. Aquilo foi uma loucura, vivenciar aquilo! O que é que significa aquilo? As pessoas não têm ideia do que significa a água no Nordeste, do ponto de vista estético, muda inclusive a concepção estética. O que é um céu bonito no Nordeste? É um céu carregado de chover, isso que é um céu bonito, "hoje está bonito para chover". É exatamente o contrário, você diz hoje que o céu está bonito quando está sol, completamente sem nuvem. Lá é o contrário: o céu está bonito quando está carregado de chover. Então, a estética é inclusive outra, a relação é outra. Gente, o gado fica feliz, isso é que é impressionante, os animais ficam felizes com a chuva, eles farejam a chuva, não é? E ficam felizes com a chuva. Os bezerros pulam no pátio, as ovelhas passando, a natureza renasce. No Nordeste é uma coisa impressionante, a caatinga se chove dois dias, no terceiro a caatinga está cheia de florezinhas nascendo, as flores nascendo sobre o chão, o sol nos caminhos, vem com uma força, que é uma coisa impressionante. Eu vivi tudo isso.

Daisy. Durval eu ia te perguntar lá no contexto da sua fala, acabou não dando. Essa reflexão que você faz sobre essa invenção do conceito de Nordeste, quem dos autores consagrados do pensamento social brasileiro começaram a introduzir essa discussão? Que autores, de certo modo, 
abriram o caminho para que você desenvolvesse suas pesquisas, quais foram as suas referências conceituais?

Durval. Um livro como a Elegia para uma Re(li)gião, de Francisco de Oliveira, é uma primeira elaboração estrutural marxista de um conceito de região. Francisco de Oliveira desnaturaliza a região, mostra a região como uma construção, embora naquele modelo de interpretação marxista. Uma professora da Universidade Federal da Paraíba, Rosa Godoy Silveira, tem um livro chamado Regionalismo Nordestino, onde ela pensa o regionalismo como uma ideologia política. O Frederico de Castro Neves, que fez um livro sobre as memórias do Nordeste, essas memórias que constituem essa ideia de Nordeste. Já existiam algumas obras que colocavam a região como uma questão, como um problema.

Nos anos de 70, 80 no Nordeste, tinha uma série de intelectuais que produziam em torno da questão regional. Eu fui muito formado por essa literatura marxista econômica e sociológica, li muito mais, na minha graduação, Economia e Sociologia do que História. Por isso, tive uma certa dificuldade depois com a narrativa. Quando escrevi o primeiro capítulo da minha dissertação, o meu orientador Robert Selenes, que é uma pessoa que tem formação em literatura latino-americana e portanto escreve super bem, disse: "você não escreve como historiador, você escreve como sociólogo e economista". Tive uma certa crise e isso foi o ponto de partida para a mudança, inclusive, da minha forma de escrever porque também eu fiz uma graduação todo vetado, por exemplo, você não podia ler Sérgio Buarque de Holanda, não podia ler Gilberto Freyre, que eram autores considerados conservadores. Então, eu li o quê? Eu lia Caio Prado Júnior, Celso Furtado, Nelson Werneck Sodré, Leôncio 
Basbaum, toda escola sociológica paulista, Francisco Oliveira, Francisco Weffort, Maria Sylvia de Carvalho Franco, Fernando Henrique Cardoso, Otávio Ianni. Essa foi a minha literatura. Li muito pouco Bóris Fausto, Carlos Guilherme Mota, Fernando Novais, que é super economicista. Então, a minha formação foi muito sociológica, mas essa questão da região já era colocada por sociólogos, só que faltava justamente a dimensão discursiva, simbólica, etc. Aí veio da minha formação do mestrado, do meu contato com Foucault.

Foucault mudou completamente minha vida. A disciplina em que eu li História da Loucura, para mim foi uma coisa transformadora, da mesma forma que Marx foi profundamente transformador. Fiz toda uma graduação marxista sem ler Marx porque ele não podia ser publicado naquele momento no Brasil, os livros ainda estavam sem circular. Fui ler Marx sistematicamente no mestrado, em uma disciplina em que a gente leu todo o Capital, foi a primeira vez que eu li Marx e descobri que ele era muito melhor que os marxistas (risos). Muito mais rico que os marxistas. Aí, em uma disciplina só, eu li Edward Palmer Thompson e Foucault. Aí Thompson já fazendo toda uma revisão do marxismo e Foucault propondo uma outra coisa. Foucault primeiro me fascinou a escrever, poder escrever História lindamente daquele jeito... Que eu nunca imaginei que loucura tivesse história! Então, isso me fascinou, e a variedade de documentos, a possibilidade de poder cruzar todo tipo de documento, usar quadros, relatos médicos, jurídicos...

Daisy. Isso você faz muito bem por sinal. Foucault Eu ouvi o Roberto Machado, ano passado, falando sobre Foucault e você é um excelente discípulo, ele era louco pelos dados, ele tinha essa fome de dados. 
Durval. Foucault é um filósofo completamente diferente porque filosofa a partir do arquivo, em vez de filosofar a partir de outros filósofos, ele filosofa a partir do arquivo. Isso que faz dele um filósofo completamente original e o faz ser também um historiador completamente diferente por ser um filósofo-historiador. Ao contrário dos historiadores que costumam ter desprezo pelo conceito e pela história dos conceitos, Foucault faz uma história dos conceitos, faz uma arqueologia dos conceitos. Ele vai para o arquivo encontrar os conceitos de época. Aquilo que eu dizia hoje: muitos historiadores naturalizavam os conceitos, achavam que o conceito não tem história, cometiam diacronismo colocando os conceitos do presente no passado. Foucault me ajudou a duplamente a perceber a importância do discurso, da análise, do conceito. Só foi possível fazer uma história sobre o conceito de Nordeste, sobre o conceito de seca, que é a minha dissertação de mestrado, na verdade por uma história do conceito da seca, quer dizer, como é que a seca se transforma em uma questão, um problema. Como o problema emerge? Que é o que Foucault coloca: como é que, em um dado momento, um problema se tornou problema? Como é que uma coisa emergiu como questão? Desde o mestrado, o movimento é muito a partir dele, do impacto dele, depois a própria figura dele...

Foucault me fascina enquanto figura, tem muitas identidades comigo: a homossexualidade, a visão meio transgressiva de mundo, meio anárquica. Ele tem uma série de coisas que me dizem muito, eu gosto da figura, não só do pensamento. Acho a figura extraordinária, o riso, a ironia, isso tem muito a ver comigo, um certo sarcasmo. Gosto muito de ler as coisas, ver as ironias, as maldades dele com os outros. Tem em Marx também, Thompson, são grandes ironistas. Marx é um grande ironista contra os 
seus adversários, as notas de rodapé de Marx são para fazer ironias com os seus adversários.

Valéria. Queria só uma última pergunta: você considera a sua identidade hoje mais rural ou mais urbana, tendo passado por toda essa trajetória?

Durval. Acho que sou um homem do mundo, eu sou cosmopolita, sou de todos os lugares e sou um ser em trânsito, sempre. Acho que o que eu justamente aprendi foi a transitar em lugares bastantes diversos, espaços diversos. Por exemplo, eu falava hoje da minha experiência da Espanha, que eu vivia em uma grande cidade, que era Barcelona, uma cidade cosmopolita, que você ouvia dez línguas diferentes por dia. Tive toda uma experiência de conhecer a Espanha profunda, os pueblos desse tamanhinho, quer dizer eu circulo muito nessas diferenças, não tenho uma identidade fixa, nacional, regional.

Valéria. Você tem, em você, todas essas experiências...

Durval. Por isso que eu gosto muito do Tropicalismo, da postura deles: nem Brasil nem Bahia, nem uma coisa nem outra. Eu sou a favor da abertura, dos fluxos, de não ter fronteiras. Essa história das identidades, para um homossexual, é uma coisa muito difícil porque justamente a homossexualidade é a tentativa de fixar uma identidade impossível. O homossexual é justamente dado pela negativa. O quê que é o homossexual? “Não é!” Não é masculino, não é feminino. Aí é melhor não pensar em identidades, não trabalhar com essa ideia de identidade, trabalhar com a ideia da diferença mesmo. Por isso que eu me encontro nas filosofias da diferença, por isso gosto das filosofias de diferença. $\mathrm{O}$ grande barato de Deleuze e Guattari é justamente assim: o pensamento não é feito para você entender, compreender, é para você usar como bate 
em você, é como lhe afeta. Deleuze é um espinoseano. Tem a ver com afeto, como é que um pensamento te afeta? O pensamento é do plano do afeto, da afeição porque o pensamento, inclusive para Deleuze, o conceito tem uma dimensão estética, o conceito também é estético, também é beleza, o pensamento também tem uma beleza, o pensamento também tem um ritmo, uma sonoridade, que afeta. Algumas coisas te afetam, outras não. Algumas coisas funcionam, outras não. Para Deleuze, o conceito funciona ou não funciona. Não é do plano do entendimento. Durante muito tempo, a gente achava que a gente tinha que dominar o conceito, saber exatamente o que ele significa, repeti-lo várias vezes na nota de rodapé. Não. O conceito é para gente fazer dele nosso. A gente realmente só aprende teoria quando faz do conceito algo nosso, quando a gente subjetiva. No texto que eu acabei de escrever sobre o ensino da teoria da história, a minha tese é justamente que ensinar teoria da história é ensinar a formação do olhar, é ensinar a olhar para o mundo de uma determinada forma (ALBUQUERQUE, 2019.). Teoria é só uma forma de olhar porque a partir da forma de olhar, vem uma forma de perguntar, de entender, de narrar. Então, a teoria forma um olhar, aquilo que você vai focalizar. Quando Thompson diz: "olhar a história de baixo”, a história vista de baixo é um olhar, é uma proposta de olhar, você olha a história de uma determinada posição. Quando Ginzburg defende a micro-história, a micro-história é um olhar, é um foco micro, ao invés do macroestrutural, você olha para o micro. Teorias sãos sempre propostas de olhar. Quando Levi-Strauss diz: “a estrutura é sempre olhar o que não está visto, o que não está visível e que está inconsciente", é você sempre ver a camada mais profunda. O estruturalismo é uma prática de lei em camadas, de sentidos, 
de localizar a camada mais invisível, mais inconsciente que é a camada estrutural. Então, o quê que Levi-Strauss fazia? Partia das coisas mais visíveis, que eram as descrições etnográficas, e ia estabelecendo relações (até matemáticas) entre aqueles elementos e ia descobrindo uma estrutura invisível que suportava toda aquela dispersão. Ou seja: com o estruturalismo a gente aprende que uma dispersão muitas vezes pode ter uma estrutura que a rege. Aquilo que parece disperso, na verdade não está disperso.

\section{Post Scriptum ${ }^{4}$}

Por Valéria Cazetta. ${ }^{5}$

O currículo lattes do professor Durval adensa uma trajetória de pesquisa-vida (que aqui eu uso hifenizada) circunscrita em torno de um gesto de ensinar, estudar e pesquisar, que tem no manejo do arquivo do mundo a força intensiva dos seus ditos e escritos. Ditos e escritos de um historiador arquivista, ancorado no espaço-tempo forjado pelas sensibilidades e emoções dos corpos em suas trajetórias humanas e inumanas.

\footnotetext{
4 Texto adaptado da apresentação de Cazetta sobre Durval Muniz para a conferência por ele proferida (com o título Identidade, Tolerância e Construção da Noção de Nordeste, em11 de novembro de 2019, na EACH/USP), após a qual foi realizada esta entrevista (por Magalhães e Perelmutter).

${ }^{5}$ Docente da EACH/USP. Orientadora no Programa de Pós-Graduação em Estudos Culturais/USP. Doutora em Geografia com pós-doutorado em educação pela Universidade do Estado de Santa Catarina (UDESC). Coordenadora do Grupo de Pesquisa em Culturas Visuais e Experimentações Geográficas/USP. https://orcid.org/0000-0001-5921-6074.
} 
A força de suas enunciações, tributárias de composições arquivísticas, é tamanha que a leitura de seus escritos, a escuta de seus ditos, catapultam-nos para espaços e tempos outros, quais sejam: aqueles espaços e tempos que somente uma escrita sensível e intempestiva pode proporcionar.

Ler A Invenção do Nordeste (2009), que já foi traduzido para o inglês em 2014; A Feira dos Mitos (2013a); Nordestino: Invenção do falo (2013b); e tantos livros e artigos publicados pelo professor Durval, é lidar com uma experiência de leitura que se dobra em nossas corporeidades. Talvez a intenção de Durval seja exatamente essa: que seu gesto de pesquisa-vida marque nossos corpos, como faz a tatuagem ao marcar permanentemente a pele com tinta. Ditos e escritos como tatuagens do arquivo do mundo em nós. Quiçá com a intenção de produzir o gesto de embaralhar as cartas para compreender que presente, passado e futuro nada mais são que montagens. Montagens de modos de vida, montagens de imaginações políticas e instituidoras de reais, como diz Durval, que habitam em nós, nesses corpos a resfolegar os ares do mundo, graças às grafias sobreviventes, adormecidas nas estantes das bibliotecas, à espera de algum gesto intempestivo, para lhe restituir à vida, à vida pesquisa-vida.

Durval, obrigada por nos ensinar o gesto da liberdade intempestiva no ato de "tornar-se" professor-pesquisador!

\section{Referências}

ALBUQUERQUE JR, D. M. de. História: a arte de inventar o passado. Ensaios de teoria da História. Bauru, Edusc, 2007a. 
Preconceito contra a origem geográfica e

de lugar: as fronteiras da discórdia. São Paulo: Cortez, 2007b.

A invenção do Nordeste e outras artes. $4^{a}$ ed. Recife: FJN; Ed. Massangana; São Paulo: Cortez, 2009. 340 p.

A Feira dos Mitos: Fabricação do folclore e da cultura popular (1920 - 1950). 2a. ed. São Paulo: Intermeios, 2013a. 254 p.

. Nordestino: Invenção do falo: Uma história do gênero masculino (1920 - 1940). São Paulo: Intermeios, 2013b. 246 p.

O Tecelão dos Tempos (novos ensaios de teoria da História). São Paulo: Intermeios, 2019. 